\title{
Kertomus Suomen Kielen Seuran toimivuodesta 1.1.-31.12.2016
}

\section{Kokoukset ja esitelmät}

Seura on kuluneena vuonna pitänyt neljä kokousta, joista kolme pidettiin kevätkaudella ja yksi syyskaudella. Lokakuulle suunniteltu kokous peruuntui esiintyjän äkillisen sairastumisen vuoksi. Kokouksiin on osallistunut yhteensä 113 henkeä seuran jäseniä ja muuta yleisöä. Syyskaudella seura piti myös Turun Kirjamessujen yhteydessä yleisöseminaarin.

17.2. Aboa Vetus \& Ars Nova -museon johtaja, museologi Johanna Lehto-Vahtera esitelmöi aiheesta Pienviljelijä August Pyölniittu (1887-1979) totuuden etsijänä. Itseoppineen tiedemiehen elämää Paimiossa.

16.3. Turun museokeskuksen tutkija, maakunta-arkeologi Kaisa Lehtonen esitelmöi aiheesta Turun keskiaikaisia kylätontteja inventoimassa - kylätontit arkeologisina kohteina.

21.4. järjestettiin seminaari teemanaan Kieli ja kulttuuri maahanmuuttajan arjessa. Ohjelmassa olivat seuraavat esitelmät: monikielisyystutkija, toimittaja ja kouluttaja, FM Satu Rakkolainen-Sossa: Kieli keskeisenä kotoutumisessa sekä erityisasiantuntija, konsultti Hannu-Pekko Huttunen: Kotoutuminen - elämää, teoriaa vai byrokratiaa? Lisäksi käytiin paneelikeskustelu, johon osallistuivat suomi toisena kielenä -opettaja, FM Hannele Mäkinen, Turun Kanava Nuoriso ry:n suunnittelija, Pohja-hankkeen toiminnanohjaaja Zahra Al Take, tapakulttuurin asiantuntija, FT Annakaisa Suominen sekä suomi toisena kielenä -kouluttaja, FM Janita Kivimäki.

Kokouksen aluksi kuultiin seuran esimiehen alkajaissanat ja jaettiin Osmo Ikolan rahaston palkinto parhaasta vuonna 2015 valmistuneesta suomen ja sen sukukielten alaan kuuluvasta pro gradu -tutkielmasta FM Sirkku Niemelle.

2.10. Turun Kirjamessujen yleisöseminaarin ohjelmassa olivat seuraavat esitelmät: professori Sirkka Saarinen: Väinämöisen kielestä nykysuomeen - rakenteeltaan uudistunut suomen kieli, dosentti Kirsi-Maria Nummila: Agricolan lainasanat ajan kulttuurivaikutteiden kuvastajina, dosentti Paula Sjöblom: Paavokin on lainaa: vaikutteille altis etunimistömme sekä FT Heini Lehtonen: Kielirajojen ylittely 2000-luvulla.

24.11. FT Nobufumi Inaba esitelmöi aiheesta Reformaation alkuajan kieliolot Turun seudulla.

\section{Julkaisutoiminta}

Seuran vuosikirjasta Sananjalasta oli ilmestymisvuorossa 58. nide.

Sananjalan toimituskuntaan ovat toimivuoden aikana kuuluneet seuraavat henkilöt: päätoimittajana dosentti Paula Sjöblom, toimitussihteerinä HuK Eeva Herrala, taloudenhoitajana FM Jaakko Antikainen sekä muina jäseninä Mikko Bentlin, Satu Grünthal, Pekka Hakamies, Kaisa Häkkinen, Jyrki Kalliokoski, Kaarina Koski, Leena Kytömäki, Päivi Lappalainen, Ritva Laury, Ildikó Lehtinen, Pekka Leimu, Harri Mantila, Sirkka Paikkala, Karl Pajusalu, Marko Pantermöller, Jari Sivonen ja Jussi Ylikoski. 


\section{Muistamiset}

Seura lähetti yhdessä Sananjalan kanssa kunniajäsenensä, professori Osmo Ikolan omaisille adressin toukokuussa 2016, ja Sananjalassa julkaistiin Ikolan muistokirjoitus. Lokakuussa seura onnitteli sihteeriään, FT Salla Nurmista lapsen syntymän johdosta.

\section{Muu toiminta}

Seuran kokouksista tiedotettiin jäsenkirjeen ja ovimainosten lisäksi seuran oman sähköpostilistan kautta. Lisäksi kokouksista ilmoitettiin mm. Turun Sanomien menovinkeissä, Turun yliopiston tapahtumakalenterissa sekä useilla sähköpostilistoilla.

\section{Seuran toimihenkilöt}

Suomen Kielen Seuran toimihenkilöinä ovat olleet 25.11.2015 kokouksessa valitut seuraavat henkilöt: esimiehenä professori Kirsti Siitonen, I varaesimiehenä professori Sirkka Saarinen, II varaesimiehenä professori Päivi Lappalainen, sihteerinä FT Salla Nurminen ja hänen sijaisenaan 1.10.-31.12. FM Katri Priiki, rahastonhoitajana FM Maija Lundgren sekä muina johtokunnan jäseninä opiskelija Antti Ainola, lehtori Inka Rautiainen, professori Helena Ruotsala, dosentti Paula Sjöblom ja yliopisto-opettaja Tanja Toropainen. Johtokunta on kokoontunut toimivuoden aikana viisi kertaa.

Seuran varsinaisina toiminnantarkastajina ovat toimineet FT Viola Čapková ja dosentti Krista Ojutkangas. Varatoiminnantarkastajina ovat olleet FT Hanneleena Hieta ja FT Tuomas Hovi.

\section{Jäsenmäärä ja jäsenmaksut}

Toimivuoden lopussa seuraan kuului 117 vakinaista jäsentä ja 69 vuosi- ja opiskelijajäsentä.

Vuosijäsenen vuosimaksu oli 20 euroa, opiskelijajäsenen vuosimaksu 5 euroa, ainaisjäsenen kertakaikkinen maksu 200 euroa ja lahjoittajajäsenen alin maksu 1000 euroa.

\section{Varallisuus ja avustukset}

Seuran varallisuus oli toimivuoden alussa 5122,99 euroa. Tieteellisten seurain valtuuskunta myönsi Suomen Kielen Seuralle vuodeksi 2016 Sananjalka 58:n julkaisemiseen 5000,oo euroa. Lisäksi Tiedekustantajien liitto myönsi seuralle Turun kirjamessuille osallistumiseen 1500 euron avustuksen. Toimivuoden lopussa seuran varallisuus oli 6093,97 euroa.

KATRi PriIki

Suomen Kielen Seuran sihteeri katri.priiki@utu.fi 